\title{
Iodine-induced Nephropathy in Patients with Oncological Disorders Treated with Chemotherapy
}

\author{
ANA MAGDALENA BRATU ${ }^{1}$, IULIA ALECSANDRA SALCIANU ${ }^{2 *}$, CONSTANTIN ZAHARIA ${ }^{3}$, \\ GHEORGHE IANA ${ }^{4}$, RAZVAN NEGREANU ${ }^{5}$, VICTORITA STEFANESCU ${ }^{6}$ \\ 1 "Carol Davila" University of Medicine and Pharmacy, Department of Radiology and Medical Imaging, "Colţea" Clinical \\ Hospital, 1 Ion C. Brătianu Av., 030171, Bucharest, Romania \\ 2 "Carol Davila" University of Medicine and Pharmacy, Department of Radiology and Medical Imaging, "Colțea" Clinical \\ Hospital, 1 Ion C. Brătianu Av., 030171, Bucharest, Romania, \\ 3 "Carol Davila" University of Medicine and Pharmacy, Department of Radiology and Medical Imaging, "Colțea" Clinical \\ Hospital, 1 Ion C. Brătianu Av., 030171, Bucharest, Romania \\ 4 "Carol Davila" University of Medicine and Pharmacy, Department of Radiology and Medical Imaging, "Colţea" Clinical \\ Hospital, 1 Ion C. Brătianu Av., 030171, Bucharest, Romania \\ ${ }^{5}$ Department of Oncology, "Colțea" Clinical Hospital, 1 Ion C. Brătianu Av., 030171, Bucharest, Romania \\ ${ }^{6}$ University of Medicine and Pharmacy "Dunărea de Jos", 47 Domneasca Str., 800008, Galați, Romania
}

Cancer represents the second most important cause of death and morbidity in Europe, with more than 3.7 million new cases and 1.9 million deaths reported each year. Computed tomography plays a fundamental role in the management of oncology patients, and the superior diagnostic value that contrast-enhanced images offer is frequently critical. It is well recognized that iodinated contrast media have a cytotoxic effect, and this is felt to be one of the mechanisms responsible for contrastinduced nephrotoxicity. The study aims to analyze the correlation between administration of iodinated contrast substance (namely, Iohexol) and serum creatinine values 48 hours afterwards in patients with oncological conditions undergoing chemotherapy, which perform CT examinations (observational study).

Keywords: CT, contrast media induced nephropathy, chemotherapy

Cancer represents the second most important cause of death and morbidity in Europe, with more than 3.7 million new cases and 1.9 million deaths reported each year [1].

Patients with cancer usually undergo several imaging examinations that generally require the intravascular administration of contrast medium (CM) [1].

Computed tomography (CT) plays a fundamental role in the management of oncology patients [2]. In the context of CT, the superior diagnostic value that contrast-enhanced images offer is frequently critical [3].

The utilization of CT in England has increased dramatically compared to a decade ago; 4.7 million CT scans were performed between April 2012 and March 2013, compared to the 1.8 million performed between 2002 and 2003 [4].

It is estimated that 80 million computed tomography scans were performed in the United States in 2010, and an annual increase of $10 \%$ is projected [5]. Most procedures are performed with iodinated contrast medium injection. However, as with any medicine, the use of contrast medium is not entirely risk-free [6].

While CT technology has evolved, the practice of CT intravenous contrast media administration has been continually debated and updated [7].

Adverse events following intravascular administration of iodinated contrast material occur in 0.02 to $0.04 \%$ of patients [8], and include kidney injury, respiratory or cardiac arrest, convulsions, and loss of consciousness [9, 10, 11]. It is well recognized that iodinated contrast media have a cytotoxic effect, and this is felt to be one of the mechanisms responsible for contrast-induced nephrotoxicity [12].

Renal insufficiency has been noted as both contributing to the risk of a post-CM adverse event and as a result thereof [13- 15].

Contrast-induced nephropathy is an acute deterioration of renal function within $48 \mathrm{~h}$ following intravascular administration of contrast medium in the absence of another likely cause $[8,16]$.

*email: salcianu_iulia@yahooc.com; Phone: +40766524703 
It has been variably defined as an increase from baseline in serum creatinine values of $25-50 \%$ or an absolute increase of $0.5-1.0 \mathrm{mg} / \mathrm{dL}$ above precontrast values within 2 or 3 days of intravascular CM administration in the absence of an alternative cause $[14,17,18,19]$.

Contrast induced renal failure has an estimated incidence of 8 to $20 \%$ of cancer patients who undergo contrastenhanced CT $[15,20]$.

The pathophysiologic mechanism of contrast median nephropathy is not fully understood but likely involves multiple factors including renal vasoconstriction which leads to renal medullary ischemia, and direct toxicity to the tubular epithelial cells [21].

The reported incidence of renal damage after contrast media administration has varied widely, ranging from $1 \%$ to $30 \%$ [16]. This wide variation in incidence can be attributed to differences in the definition of contrast-induced nephropathy used, differing patient populations, variability of contrast doses, variations in timing of follow-up, and different routes of contrast medium administration (intra-arterial vs. intravenous) [22].

Another study conducted by Del Mastro [1] indicates that nephropathy caused by iodinated CM that occurs in $2.3 \%$ of all CT examinations.

Pre-existing renal insufficiency is the most important risk factor for renal failure after CM administration [23]. The poorer the renal function, the higher the risk of acute renal injury related to CM [24].

The other risks of developing this complication are compounded by several patient conditions, such as advanced age (>70 years), dehydration and co-administration of nephrotoxic chemotherapeutic drugs or nephrotoxic drugs [1, 16], diabetes mellitus, hypertension, multiple myeloma, hyperuricemia [16].

Most commonly, acute renal failure after CM manifests as a non-oliguric and transient decline in renal function, with the serum creatinine level rising within $24 \mathrm{~h}$, peaking in 3-5 days, and returning to baseline within 10-14 days [1, 25]. Oliguric acute renal failure requiring dialysis is much less common [26], but is associated with a significantly higher morbidity and mortality rate [27].

The study aims to analyze the correlation between administration of iodinated contrast substance and serum creatinine values 48-72 hours afterwards in patients with oncological conditions undergoing chemotherapy, which perform CT examinations (observational study).

The data obtained could have practical implications for the management of renal disease in this type of patient.

\section{Experimental part}

\section{Material and methods}

The study was conducted over a period of 6 months beginning on 01.06.2018 and included patients admitted to the Oncology Department of the "Colţea" Clinical Hospital in Bucharest, who had an indication for a CT scan with administration of intravenous iodine contrast substance. Creatinine values were determined one day before CT, and at 24 and 48 hours after.

Patients were divided into two groups, as follows:

a)Untreated patients

b)Patients undergoing chemotherapy

Inclusion criteria:

- Over 18 years of age

- Patients undergoing chemotherapy

- Normal kidney function

Exclusion criteria:

- Pre-existing renal insufficiency

- History of renal transplantation

- Patients undergoing dialysis

- Known allergies

In this study, 59 patients were analyzed according to the inclusion and exclusion criteria, all of whom were diagnosed with a type of neoplasia.

Computed tomography (CT) was used in all 59 cases under study, this being necessary both for the diagnosis and for their cancer staging.

The characteristics of the equipment, the contrast agent used and the technique of its administration were as follows:

-CT-Siemens Duo Emotion, multislice of 5mm, contiguous, FOV 200, KV 130, mA 100, mAs 58.

-Iodinated water-soluble contrast substance, $350 \mathrm{mg} / \mathrm{mL}$, administered intravenously with the injector, with a flow rate of at least $2.5 \mathrm{~mL} / \mathrm{s}$, with a delay of 25 seconds until the first postcontrast acquisition.

-Multiplanar Reconstruction (MPR) in the other 2 plans (sagittal and coronal). 
-Bone window reconstruction.

According to the prospectus of the contrast substance, the active substance is Iohexol, having the content per milliliter of $755 \mathrm{mg}$ equivalent to $350 \mathrm{mg}$ of iodine. Iohexol is an X-ray contrast agent, water-soluble, tri-iodate, monomeric, nonionic.

Iohexol, is sold under the trade name Omnipaque ${ }^{\circledR}$, and its osmolarity and viscosity values are listed in tabel 1:

Table 1

THE OSMOLARITY AND VISCOSITY OF IOHEXOL

\begin{tabular}{|c|c|c|c|}
\hline \multirow{2}{*}{ Concentration } & \multirow{2}{*}{$\begin{array}{c}\text { Osmolarity } \\
\text { Osm/kg H2O } \\
\text { 37EC }\end{array}$} & \multicolumn{2}{|c|}{$\begin{array}{c}\text { Viscosity } \\
\text { mPa*s }\end{array}$} \\
\cline { 3 - 4 } & 0.51 & 5.6 & $37 \mathrm{EC}$ \\
\hline $240 \mathrm{mg} \mathrm{I} / \mathrm{ml}$ & 0.64 & 11.6 & 3.3 \\
\hline $300 \mathrm{mg} \mathrm{I} / \mathrm{ml}$ & 0.78 & 23.3 & 6.1 \\
\hline $350 \mathrm{mg} \mathrm{I} / \mathrm{ml}$ & &
\end{tabular}

Iohexol is an aqueous clear solution, colorless to pale yellow, sterile, without visible particles, used for injection administration, and has the following therapeutic indications:

-As the contrast agent for cardioangiography, arteriography, urography, flebography in adults and children and for contrast enhancement in computed tomography (CT); for lumbar, thoracic, cervical myelography and basal cavity tomography, after subarachnoid injection.

- For arthrography, endoscopic retrograde pancreatography (ERP), endoscopic retrograde cholangio-pancreatography (ERCP), herniography, hysterosalpingography, sialography, and radiological examinations of the gastrointestinal tract.

The dose administered varies depending on the nature of the exam, age, weight, heart rate, clinical situation and technique. As a rule, the volume and concentration of iodine required are the same as for other iodine contrast agents commonly used in radiology. As with other contrast agents, the patient should be properly hydrated before and after Omnipaque ${ }^{\circledR}$ administration.

The product is usually administered intravascularly or intrathecally. For CT examination the concentration administered for $350 \mathrm{mg} \mathrm{I} / \mathrm{ml}$ the volume injected should be between $100 \mathrm{ml}$ and $150 \mathrm{ml}$. In order to minimize the possible adverse reactions, a total dose of $3 \mathrm{~g}$ iodine should not be exceeding.

The chemical formula of iohexol (Omnipaque $($ ) is $C 19 H 26 I 3 N 3 O 9$ (as seen in Figure 1), also as:

5-[N-(2,3-Dihydroxypropyl)acetamido]-2,4,6-triiodo- $N, N$ '-bis(2,3-dihydroxypropyl)isophthalamide, and the molar mass of Iohexol is $821.138 \mathrm{~g} / \mathrm{mol} \mathrm{g} \cdot \mathrm{mol}-1$

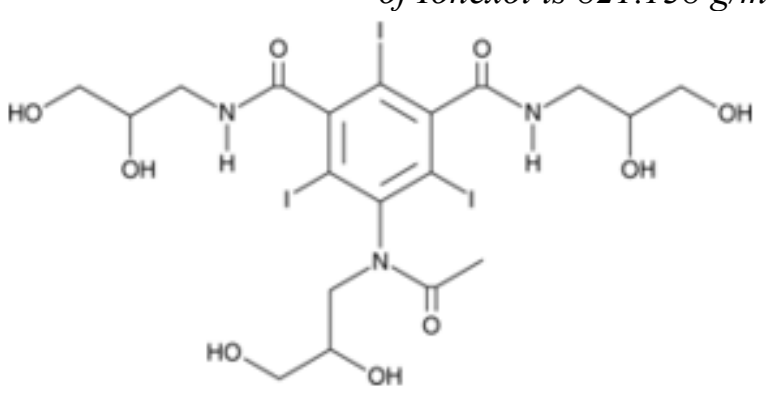

Fig.1. Iohexol

\section{Results and discussions}

In this group of 59 patients with diagnosed neoplasia, all investigated with contrast enhanced computed tomography, the median age was 59.69 years, with a rage of 39-81 years, and a male: female rate of 1:1.26.

Of them, 56 subjects were undergoing chemotherapy, and the remaining 3 patients were untreated at the time of CT examination.

Of the 56 patients who received chemotherapy, 39.28\% received 1 single chemotherapeutic drug, and $21.42 \%$ were treated with a combination of 2 chemotherapeutics; the rest of the patients were treated with a combination of 3 or more drugs.

The chemotherapeutic agents used in the single drug group were Docetaxel (in 6 patients), Capecitabina (for 6 subjects), Gemcitabine (4 cases), Topotecan (3 patiens), and Paclitaxel (3 cases). In the group of patients treated with a combination of 2 drugs, 2 cases received Docetaxel and Trastuzumab, 7 were treated with Pemetrexed and Carboplatin, and the remaining patients were treated with Doxorubicin and Cyclophosphamide. The combinations used in the group of patients who received 3 or more drugs were: Paclitaxel / Bevacizumab / Zoledronic acid (4 cases), Capecitabine / 
Irinotecan / Bevacizumab (3 cases), Fluorouracil / Carboplatin / Cetuximab (9 cases), Capecitabine / Oxaliplatin / Bevacizumab / Zoledronic acid (3 cases), and Bleomicine / Etoposid / Cisplatin (3 cases).

In the study group, regardless of the drug used or the combination of administered chemotherapy, it was observed that creatinine levels increased post-administration of contrast substance during CT examination in a number of 29 patients; the rest of the patients studied had a lower level of creatinine at 48 hours post-intravenous administration of contrast media.

Of the 29 patients whose creatinine levels increased, 19 subjects had an increase of less than $25 \%$ from baseline, 7 patients showed a $25 \%$ to $50 \%$ increase from the reference value, and 3 an increase of more than $50 \%$ in creatinine versus initial value.

It should be noted that in the group of patients with an increase of less than $25 \%$, in $47.36 \%$ of cases there was an exceeding of the upper normal limit of creatinine (i.e. over $1.2 \mathrm{mg} / \mathrm{dl}$ ). This was observed in patients treated with Topotecan ( 3 cases) and Capecitabine ( 2 cases), a combination of fluorouracil / carboplatin / cetuximab ( 3 cases), but also at a patient who was not undergoing chemotherapy at the time of the CT examination of the contrast media.

It should be also specified that patients who had an increase in creatinine of $25-50 \%$ did not exceed the creatinine threshold. They were treated with a combination of 2 drugs (doxorubicin / cyclophosphamide) or 3 chemotherapeutic agents (paclitaxel / bevacizumab / zoledronic acid, respectively, fluorouracil / carboplatin / cetuximab).

All patients who had a creatinine increase of over 50\% were treated with a combination of paclitaxel / bevacizumab / zoledronic acid, but it should be specified that the absolute value of creatinine did not exceed the normal value of $1.2 \mathrm{mg} /$ dl.

For all patients analyzed in this study, creatinine clearance $\left(\mathrm{C}_{\mathrm{Cr}}\right)$ was calculated. It was observed that in 5 patients it remained the at the same value post-administration of the contrast substance (in 4 cases the absolute value of creatinine decreased by $0.08-0.01$ units, and in one case increased by 0.02 units).

However, 30 of the patients showed a lower clearance score with 2-54 units (Table 2).

Table 2

DISTRIBUTIN ON CASES RELATED TO THE INCREASE OF $\mathrm{C}_{\mathrm{Cr}}$ (IN UNITS)

\begin{tabular}{|l|c|c|c|}
\hline Postcontrast $\mathrm{C}_{\mathrm{Cr}}$ & $<20$ units & $20-50$ units & $>50$ units \\
\hline No of cases & 24 & 2 & 4 \\
\hline
\end{tabular}

All 4 cases with a lower $C_{C r}$ with more than 50 units had an absolute value of over $80 \mathrm{~mL} / \mathrm{min} / 1.73 \mathrm{~m} 2$ and had as treatment the combination of paclitaxel / bevacizumab / zoledronic acid; in those with a decrease of $\mathrm{C}_{\mathrm{Cr}}$ between 20 and 50 units, one patient had an absolute value of $46 \mathrm{~mL} / \mathrm{min} / 1.73 \mathrm{~m} 2$, and the other had a value of $71 \mathrm{~mL} / \mathrm{min} / 1.73 \mathrm{~m} 2$, and were undergoing therapy with doxorubicin / cyclophosphamide, and respectively fluorouracil / carboplatin / cetuximab.

If we analyzed the absolute value of the cases with decreased post-contrast creatinine clearance, it was observed that 4 patients had a value of $60 \mathrm{~mL} / \mathrm{min} / 1.73 \mathrm{~m} 2$ (precontrast value ranging between $69 \mathrm{~mL} / \mathrm{min} / 1.73 \mathrm{~m} 2 \mathrm{an} 73 \mathrm{~mL} / \mathrm{min} /$ $1.73 \mathrm{~m} 2$ ), and 7 patients had a $\mathrm{C}_{\mathrm{Cr}}$ value under $60 \mathrm{~mL} / \mathrm{min} / 1.73 \mathrm{~m} 2$ (i.e. $46-59 \mathrm{~mL} / \mathrm{min} / 1.73 \mathrm{~m} 2$, with baseline values of $60-69 \mathrm{~mL} / \mathrm{min} / 1.73 \mathrm{~m} 2$. Also, in 13 cases it was identified a CCr of $71-92 \mathrm{~mL} / \mathrm{min} / 1.73 \mathrm{~m} 2$ (precontrast value: $82-142 \mathrm{~mL} / \mathrm{min} / 1.73 \mathrm{~m} 2)$ and 6 cases with values between $126-157 \mathrm{~mL} / \mathrm{min} / 1.73 \mathrm{~m} 2(128-168 \mathrm{~mL} / \mathrm{min} / 1.73 \mathrm{~m} 2$ values before the CT scan).

In the group with postcontrast $\mathrm{C}_{\mathrm{Cr}}$ lower than $60 \mathrm{~mL} / \mathrm{min} / 1.73 \mathrm{~m} 2$, there were 3 patients who received Docetaxel as treatment, and three other patients who were treated with a combined chemotherapeutics of doxorubicin / cyclophosphamide; the last was treated with gemcitabine.

In the group with a value of creatinine clearance after the contrast administration of $60 \mathrm{~mL} / \mathrm{min} / 1.73 \mathrm{~m} 2$, two patients were treated with paclitaxel / carboplatin, and one with Capecitabine. One of this subgroup was not undergoing chemotherapy.

Acute kidney failure is commonly defined as an abrupt decrease in renal function and clinically manifests as a reversible acute increase in nitrogen waste products that is determined by measuring blood urea nitrogen and serum creatinine levels over the course of hours to weeks (i.e. $>50 \%$ increase in creatinine value) $[8,28]$.

The prevalence of renal insufficiency among cancer patients is high [29] and numerous factors and patient characteristics contribute to the increased risk of developing renal failure in this patient population [30].

In a study including 37267 cancer patients, the risk of acute kidney injury was approximately $17.5 \%$ within 1 year of a cancer diagnosis and $27 \%$ after 5 years [31], and the rate of acute renal failure in patients with cancer seems to be higher than the rate reported for patients without cancer (12 vs. 5-8\% respectively) [31,33].

The chance for developing acute kidney injury is significantly higher for patients receiving chemotherapy, and those given an intravenous injection of contrast media [34]. 
Cancer treatments as well as the timing of treatment and CT imaging have been investigated as risk factors for acute reactions to iodinated CM $[35,36]$.

The route of administration is extremely important when assessing the risk of nephrotoxicity associated with contrast median administration. The rate of nephrotoxicity is 2-4 times higher in patients who undergo intra-arterial contrast medium injection compared with those who receive intravenous injection (e.g., CT). The reasons for this difference are well known [37, 38] and the benefits of using intravenous contrast are well acknowledged [7, 39]. Iodine in a target organ or blood plasma causes greater absorption and scattering of $\mathrm{x}$-ray radiation. This results in an increase in CT attenuation and contrast medium enhancement on the CT image [7].

While the biomedical literature indicates that the rate of adverse events associated with contrast media use is low, there is little evidence examining the use of contrast substance and the risk of renal impairment in individuals with cancer [8].

However, the incidence of nephropathy specifically caused by iodinated substances is not well understood [8], and was studied by investigators in association with the contrast material volume adjusted for renal function [40,41].

It has been suggested that contrast induced renal acute failure may develop 4.5 times more frequently in cancer patients who undergo recent chemotherapy [30], and that exposure to contrast within a week prior to nephrotoxic chemotherapeutic agents significantly increases the risk of nephropathy [42].

Evidence of the reduced incidence of post-contrast renal injury in the general population and patients with cancer who have received iso-osmolar contrast media has emerged from several studies, including systematic reviews and metaanalyses [43].

Different contrast substances have been developed, each with their own pharmacological characteristics [44].

The most important feature for determining the risk of nephrotoxicity seems to be the osmolality of the contrast media, and the risk is higher for agents with increased osmolality compared to that of iso-osmolar contrast media [45]

Several guidelines recommend that contrast agents with the lowest osmolality should be used and high-risk patients should be administered iso-osmolar contrast media, regardless of the administration route [46].

Based on the Onco-Nephrology Curriculum of the American Society of Nephrology, high-osmolar (>1,400 mOsm/kg) and low osmolar $(600-800 \mathrm{mOsm} / \mathrm{kg}$ ) contrast substance are associated with a higher incidence of acute renal failure compared to iso-osmolar ones $(300 \mathrm{mOsm} / \mathrm{kg})$ [1].

Some guidelines identifying management standards were issued in 2010 and updated in 2015 [47], and stated that risk factors should be assessed for all patients prior to intravenous contrast administration, glomerular filtration rate should be assessed for all non-emergency patients, and a minimum rate of $>60 \mathrm{ml} / \mathrm{min} / 1.73 \mathrm{~m} 2$ is recommended.

It been suggested that patients with active cancer undergoing enhanced CT are particularly at risk of renal failure even in the absence of significant renal impairment as underlying renal insufficiency may be masked due to falsely low creatinine concentration resulting from diminished muscle mass [48].

Cicin et al. [30] reported an incidence of acute renal injury after enhanced CT in oncology patients of $20 \%$, and was developed 4.5 times more frequently in patients with cancer who had undergone a CT within 45 days after their last chemotherapy treatment, which was also considered an independent risk factor. Also, in patients with cancer who require CT with contrast media, the risk of developing renal failure was 4.09 [48].

Several factors contribute to the increased risk, including the type and volume of contrast media, frequency of contrastenhanced imaging, comorbidities, underlying renal function and chemotherapies [28, 43, 46].

It is not difficult to surmise why cancer patients may be particularly susceptible to renal events given their high prevalence of renal insufficiency, and concomitant nephrotoxic chemotherapeutic regimens, and predisposition to dehydration (secondary to advanced age, poor appetite, nausea, and vomiting) [16].

Our results showed that serum creatinine increased in almost half of the patients $(49.15 \%) 48$ hours after CT with intravenous administrated contrast media; of these only 3 patients had an increase over $50 \%$ of the creatinine value, namely acute renal failure associated with enhanced CT.

In the study of $\mathrm{Ng}$ et al. [3] is stated that creatinine value increased in more than one half the patients (55\%) after CT with contrast medium, most of them having the maximum rise within 2 days after $\mathrm{CT}$, with a declining frequency over time.

In another study [49], an acute increase in serum creatinine was observed in $10 \%$ of patients with pre-existing renal insufficiency who received contrast medium.

In our study, all the patients from the subgroup of cases of who had an increase of creatinine over $50 \%$ were treated with a combination of Paclitaxel / Bevacizumab / Zoledronic acid. This makes us affirm that this combination of chemotherapy is the most nephrotoxic combination of drugs used in patients in our study. However, it should be mentioned that the absolute value of creatinine did not exceed the normal value of $1.2 \mathrm{mg} / \mathrm{dl}$.

According to the Renal Insufficiency and Anticancer Medications [50], 50-60\% of cancer patients who are undergoing antineoplastic treatment develop a renal impairment, and therefore medications play a critical role [1]. 
The combination Bevacizumab / Irinotecan administration on a patient with hypertension may be additional risk factors for renal failure induced by contrast agents [30], and Ifosphamide and platinum agents (Cisplatin and Carboplatin) cause both glomerular and tubular impairment [1].

The incidence and severity of renal toxicity increases with repeated usage of cisplatin-based chemotherapy, and renal injury may subsequently become irreversible [1]. Thus, cisplatin discontinuation is generally indicated in patients who present signs of progressive renal failure [51].

According to Launay-Vacher et al. [52] many patients are on concurrent nephrotoxic chemotherapeutic drugs, like Gemcitabine, Carboplatin, Doxorubicin, Paclitaxel, Cisplatin, Irinotecan, Trastuzumab, Zoledronate Acid.

The effects of the administration of CM and chemotherapy within a short time have been widely investigated [1]. Exposure to contrast substance within a week before cisplatin administration increased the risk of kidney damage by 2.56 [51].

Cetuximab induces hypomagnesemia resulting from a renal magnesium leak. Bevacizumab induces hypertension and kidney-specific injury, including proteinuria and acute renal failure [1].

Glomerular filtration rate (GFR) is considered a more reliable measure of renal function than serum creatinine [53].

In the study group was found that 30 cases had a decrease of creatinine clearance, between 2 and 54 units. In $6.77 \%$ of cases studied, a decrease was found to be below $60 \mathrm{~mL} / \mathrm{min} / 1.73 \mathrm{~m} 2$, and those patients were treated with Docetaxel, Gemcitabine, or the combination of Doxorubicin / Cyclophosphamide.

$\mathrm{Ng}$ et al. [3] found in their research that serum creatinine after CT increased compared with baseline pre-CT values in more than one half the patients (57\%), and more than one half (54\%) of these increases occurring within 2 days of CT. In evaluating the effect of undergoing CT on subsequent renal function, they detected a significant increase in creatinine (mean rise $0.25 \mathrm{mg} / \mathrm{dL}$ ) and fall in GFR (mean fall $9.38 \mathrm{~mL} / \mathrm{min} / 1.73 \mathrm{~m} 2$ ), after the administration of IV contrast medium in association with CT.

In our study, there were 4 patients with a decrease of $\mathrm{C}_{\mathrm{Cr}}$ with more than 50 units, and 2 cases with a fall of 20-50 units after 48 hours postcontrast CT. The rest of cases had a fall less than 20 units, with an overall mean decline of 14.63 $\mathrm{mL} / \mathrm{min} / 1.73 \mathrm{~m} 2$.

Regardless of the cause, cancer patients who develop renal failure may have worse prognosis and survival [54,55].

\section{Conclusions}

Although the batch of patients is not high, the study results that under the circumstances of a proper hydration of patients administration of intravenous contrast substance of the type Iohexol which is an X-ray contrast agent, watersoluble, tri-iodate, monomeric, non-ionic, does not damage renal funtion, without causing acute kidney failure, regardless of the type of drug association.

\section{References}

1. Del MASTRO, L., LAGHI, A., RONCO, C. METHODS TO ADDRESS COMPUTED TOMOGRAPHY-RELATED RISK FACTORS IN ONCOLOGY PATIENTS: AN EXPERT OPINION BASED ON CURRENT EVIDENCE. Blood Purification, 46, no 1, 2018, p. 56.

2. PERRIN, E., JACKSON, M., GRANT, R., LLOYD, C., CHINAKA, F., GOH, V. WEIGHT-ADAPTED IODINATED CONTRAST MEDIA ADMINISTRATION IN ABDOMINO-PELVIC CT: CAN IMAGE QUALITY BE MAINTAINED? Radiography (Lond), 24, no. 1, 2018, p. 22. 3. NG, C., S., SHAW, A., D., BELL, C., S., SAMUELS, J., A. EFFECT OF IV CONTRAST MEDIUM ON RENAL FUNCTION IN ONCOLOGIC PATIENTS UNDERGOING CT IN ICU. Am J Roentgenol, 195, no. 2, 2010, p. 414.

4. NHS ENGLAND. NHS IMAGING AND RADIODIAGNOSTIC ACTIVITY IN ENGLAND, NATIONAL STATISTICS, 2013. Available at: http://www.england.nhs.uk/statistics/wp-content/uploads/sites/2/2013/04/KH12-release-2012-13.pdf

5. BRENNER, D., J., HRICAK, H. RADIATION EXPOSURE FROM MEDICAL IMAGING: TIME TO REGULATE? JAMA, 304, 2010, p. 208. 6. SILVA, H., BITENCOURT, A., CHOJNIAK, R. EXTRAVASATION OF IODINATED CONTRAST MEDIUM IN CANCER PATIENTS UNDERGOING COMPUTED TOMOGRAPHY. Radiologia brasileira, 51, no. 4, 2018, p. 236.

7. BAE, K., T. INTRAVENOUS CONTRAST MEDIUM ADMINISTRATION AND SCAN TIMING AT CT: CONSIDERATIONS AND APPROACHES, Radiology, 256, no. 1, 2010, p.32

8. NG, C., S. , KALVA, S., P., GUNNARSSON, C., RYAN, M., P. , BAKER, ERIN., R., MEHTA R., L. RISK OF RENAL EVENTS FOLLOWING INTRAVENOUS IODINATED CONTRAST MATERIAL ADMINISTRATION AMONG INPATIENTS ADMITTED WITH CANCER A RETROSPECTIVE HOSPITAL CLAIMS ANALYSIS, Cancer Imaging, 18, no.30, 2018.

9. BOTTINOR, W., POLKAMPALLY, P., JOVIN, I. ADVERSE REACTIONS TO IODINATED CONTRAST MEDIA. Int J Angiol, 22, 2013, p. 149.

10. ROCKOW, K., CHRISTIANSEN, C., KANNY, G., CLEMENT, O., BARBAUD, A., BIRCHER, A., DEWACHTER, P., GUÉANT, J., L., RODRIGUEZ GUÉANT, R., M., MOUTON-FAIVRE, C., RING, J., ROMANO, A., SAINTE-LAUDY, J., DEMOLY, P., PICHLER, W., J. MANAGEMENT OF HYPERSENSITIVITY REACTIONS TO IODINATED CONTRAST MEDIA. Allergy, 60, 2005 , p.150.

11. MORCOS, S.,K., THOMSEN, H.S. ADVERSE REACTIONS TO IODINATED CONTRAST MEDIA. Eur Radiol, 11, 2001, p. 1267.

12. HALLER, C., HIZOH, I. THE CYTOTOXICITY OF IODINATED RADIOCONTRAST AGENTS ON RENAL CELLS IN VITRO. InVest Radiol, 39, 2004, p. 149. 
13. MEHRAN, R., NIKOLSKY, E. CONTRAST-INDUCED NEPHROPATHY: DEFINITION, EPIDEMIOLOGY, AND PATIENTS AT RISK. Kidney Int Suppl, 100, 2006, p. 11.

14. MIZUNO, T., SATO, W., ISHIKAWA, K., SHINJO, H., MIYAGAWA, Y., NODA, Y., IMAI, E., YAMADA, K. KDIGO (KIDNEY DISEASE: IMPROVING GLOBAL OUTCOMES) CRITERIA COULD BE A USEFUL OUTCOME PREDICTOR OF CISPLATIN-INDUCED ACUTE KIDNEY INJURY. Oncology, 82, 2012, p. 354.

15. RAWSON, J., V., PELLETIER, A., L. WHEN TO ORDER A CONTRAST-ENHANCED CT. Am Fam Physician, 88, 2013 , p. 312.

16. HEIKEN, J., P. CONTRAST SAFETY IN THE CANCER PATIENT: PREVENTING CONTRAST-INDUCED NEPHROPATHY. Cancer imaging: the official publication of the International Cancer Imaging Society, 8, Spec No A, 2008, p. 124.

17. ENG, J., WILSON, R., F., SUBRAMANIAM, R., M., ZHANG, A., SUAREZ-CUERVO, C., TURBAN, S., CHOI, M.,J., SHERROD, C., HUTFLESS, S., IYOHA, E., E., BASS, E., B. COMPARATIVE EFFECT OF CONTRAST MEDIA TYPE ON THE INCIDENCE OF CONTRAST-INDUCED NEPHROPATHY: A SYSTEMATIC REVIEW AND META-ANALYSIS. Ann Intern Med, 164, 2016, p. 417.

18. THOMSEN, H., S. GUIDELINES FOR CONTRAST MEDIA FROM THE EUROPEAN SOCIETY OF UROGENITAL RADIOLOGY. AJR Am J Roentgenol, 181, 2003, p. 1463.

19. McCULLOUGH, P., A., SANDBERG, K., R. EPIDEMIOLOGY OF CONTRAST-INDUCED NEPHROPATHY. Rev Cardiovasc Med, 4, Suppl 5, 2003, p. 3 .

20 HUANG, M., K., HSU, T., F., CHIU, Y., H., CHIANG, S., C., KAO, W., F., YEN DH, HUANG, M., S. RISK FACTORS FOR ACUTE KIDNEY INJURY IN THE ELDERLY UNDERGOING CONTRAST-ENHANCED COMPUTED TOMOGRAPHY IN THE EMERGENCY DEPARTMENT. J Chin Med Assoc, 76, 2013, p. 271.

21. RUDNICK, M.,R., KESSELHEIM, A., GOLDFARB, S. CONTRAST-INDUCED NEPHROPATHY: HOW IT DEVELOPS, HOW TO PREVENT IT. Cleve Clin J Med, 73, 2006, p. 75.

22. KATZBERG, R., W., BARRETT, B., J. RISK OF IODINATED CONTRAST MATERIAL-INDUCED NEPHROPATHY WITH INTRAVENOUS ADMINISTRATION. Radiology, 243, 2007, p. 622.

23. MORCOS, S., K., THOMSEN, H., S., WEBB, J., A. CONTRAST-MEDIA-INDUCED NEPHROTOXICITY: A CONSENSUS REPORT. Contrast Media Safety Committee, European Society of Urogenital Radiology (ESUR) Eur Radiol, 9, 1999, p. 1602.

24. FINN, W., F. THE CLINICAL AND RENAL CONSEQUENCES OF CONTRAST-INDUCED NEPHROPATHY. Nephrol Dial Transplant, 21, Suppl 1, 2006, p. 2.

25. GLEESON, T., G., BULUGAHAPITIYA, S. CONTRAST-INDUCED NEPHROPATHY. AJR Am J Roentgenol, 183, 2004, p. 1673.

26. KATZBERG, R., W. UROGRAPHY INTO THE 21ST CENTURY: NEW CONTRAST MEDIA, RENAL HANDLING, IMAGING CHARACTERISTICS, AND NEPROTOXICITY. Radiology, 2014, 1997, p. 297.

27. ANDERSON, R., J., LINAS, S., L., BERNS, A., S., HENRICH, W., L., MILLER, T., R., GABOW, P., A., SCHRIER, R., W. NON-OLIGURIC ACUTE RENAL FAILURE. N Engl J Med, 296, 1977, p. 1134.

28. KHWAJA, A. KDIGO CLINICAL PRACTICE GUIDELINES FOR ACUTE KIDNEY INJURY. Nephron Clin Pract, 120, 2012 , p. 179.

29. DOGAN, E., IZMIRLI, M., CEYLAN, K., ERKOC, R., SAYARLIOGLU, H., BEGENIK, H., ALICI, S. INCIDENCE OF RENAL INSUFFICIENCY IN CANCER PATIENTS. Adv Ther, 22, 2005, p. 357.

30. CICIN, I., ERDOGAN, B., GULSEN, E., UZUNOGLU, S., SUT, N., TURKMEN, E., KODAZ, H., USTUNDAG, S. INCIDENCE OF CONTRAST-INDUCED NEPHROPATHY IN HOSPITALISED PATIENTS WITH CANCER. Eur Radiol, 24, 2014, p. 184.

31. CHRISTIANSEN, C., F., JOHANSEN, M., B., LANGEBERG, W., J., FRYZEK, J., P., SORENSEN, H., T. INCIDENCE OF ACUTE KIDNEY INJURY IN CANCER PATIENTS: A DANISH POPULATION-BASED COHORT STUDY. Eur J Intern Med, 22, 2011 , p. 399.

32. SELBY, N., M., CROWLEY, L., FLUCK, R., J., MCINTYRE, C., W., MONAGHAN, J., LAWSON, N., KOLHE, NV. USE OF ELECTRONIC RESULTS REPORTING TO DIAGNOSE AND MONITOR AKI IN HOSPITALIZED PATIENTS. Clin J Am Soc Nephrol, 7, 2012 , p. 533.

33. CHERTOW, G., M., BURDICK, E., HONOUR, M., BONVENTRE, J., V., BATES, D., W. ACUTE KIDNEY INJURY, MORTALITY, LENGTH OF STAY, AND COSTS IN HOSPITALIZED PATIENTS. J Am Soc Nephrol, 16, 2005, p. 3365.

34. SALAHUDEEN, A., K., DOSHI, S., M., PAWAR, T., NOWSHAD, G., LAHOTI, A., SHAH, P. INCIDENCE RATE, CLINICAL CORRELATES, AND OUTCOMES OF AKI IN PATIENTS ADMITTED TO A COMPREHENSIVE CANCER CENTER. Clin J Am Soc Nephrol, 8, 2013, p. 347.

35. FAROLFI, A., CARRETTA, E., LUNA, C., D., RAGAZZINI, A., GENTILI, N., CASADEI, C., BARONE, D., MINGUZZI, M., AMADORI, D., NANNI, O., GAVELLI, G. DOES THE TIME BETWEEN CT SCAN AND CHEMOTHERAPY INCREASE THE RISK OF ACUTE ADVERSE REACTIONS TO IODINATED CONTRAST MEDIA IN CANCER PATIENTS? BMC Cancer, 14, 2014 , p. 792.

36. FAROLFI, A., Della LUNA, C., RAGAZZINI, A., CARRETTA, E., GENTILI, N., CASADEI, C., AQUILINA, M., BARONE, D., MINGUZZI, M., AMADORI, D., NANNI, O., GAVELLI, G. TAXANES AS A RISK FACTOR FOR ACUTE ADVERSE REACTIONS TO IODINATED CONTRAST MEDIA IN CANCER PATIENTS. Oncologist, 19, 2014, p. 823.

37. KEELEY, E., C., GRINES, C., L. SCRAPING OF AORTIC DEBRIS BY CORONARY GUIDING CATHETERS: A PROSPECTIVE EVALUATION IN 1,000 CASES. J Am Coll Cardiol, 32, 1998, p. 1861.

38. RAMIREZ, G., O'NEILL, W., M., LAMBERT, R, BLOOMER, H., A. CHOLESTEROL EMBOLIZATION: A COMPLICATION OF ANGIOGRAPHY. Arch Intern Med, 138, 1978, p. 1430.

39. WRIGHT, J., G., BODDY, A., V., HIGHLEY, M., FENWICK, J., CALVERT, A., H., L. ESTIMATION OF GLOMERULAR FILTRATION RATE IN CANCER PATIENTS. Br J Cancer, 84, 2001, p.452.

40. CIGARROA, R., G., LANGE, R., A, WILLIAMS, R., H., HILLIS, L., D. DOSING OF CONTRAST MATERIAL TO PREVENT CONTRAST NEPHROPATHY IN PATIENTS WITH RENAL DISEASE . Am J Med, 86, no. 6, 1989, p. 649.

41. VLIETSTRA, R., E., NUNN, C., M., NARVARTE, J., BROWNE, K., F. CONTRAST NEPHROPATHY AFTER CORONARY ANGIOPLASTY IN CHRONIC RENAL INSUFFI CIENCY. Am Heart J, 132, no. 5, 1996, p. 1049.

42. McDONALD, R., J, McDONALD, J., S., CARTER, R., E., HARTMAN, R., P., KATZBERG, R., W., KALLMES, D., F., WILLIAMSON, E., E. INTRAVENOUS CONTRAST MATERIAL EXPOSURE IS NOT AN INDEPENDENT RISK FACTOR FOR DIALYSIS OR MORTALITY. Radiology, 273, 2014, p. 714. 
43. STACUL, F., Van Der MOLEN, A., J., REIMER, P., WEBB, J., A., THOMSEN, H., S., MORCOS, S., K., ALMÉN, T., ASPELIN, P., BELLIN, M., F., CLEMENT, O., HEINZ-PEER, G. CONTRAST MEDIA SAFETY COMMITTEE OF EUROPEAN SOCIETY OF UROGENITAL RADIOLOGY (ESUR): CONTRAST INDUCED NEPHROPATHY: UPDATED ESUR CONTRAST MEDIA SAFETY COMMITTEE GUIDELINES. Eur Radiol, 21, 2011, p. 2527.

44. DAVIDSON, C., STACUl, F., McCUllough, P., A., TUMLIN, J., ADAM, A., LAMEIRE, N., BECKER, C., R., CIN CONSENSUS WORKING PANEL. CONTRAST MEDIUM USE. Am J Cardiol, 98, 2006, p. 42.

45. McCULLOUGH, P., A., BROWN, J., R. EFFECTS OF INTRAARTERIAL AND INTRAVENOUS ISO-OSMOLAR CONTRAST MEDIUM (IODIXANOL) ON THE RISK OF CONTRAST-INDUCED ACUTE KIDNEY INJURY: A META-ANALYSIS. Cardiorenal Med, 1, 2011 , p. 220. 46. WINDECKER, S., KOLH, P., ALFONSO, F., COLLET, J., P., CREMER, J., FALK, V., FILIPPATOS, G., HAMM, C., HEAD, S., J., JÜNI, P., KAPPETEIN, A., P., KASTRATI, A., KNUUTI, J., LANDMESSER, U., LAUFER, G., NEUMANN, F., J., RICHTER, D., J., SCHAUERTE, P., SOUSA UVA, M., STEFANINI, G., G., TAGGART, D., P., TORRACCA, L., VALGIMIGLI, M., WIJNS, W., WITKOWSKI, A. 2014 ESC/EACTS GUIDELINES ON MYOCARDIAL REVASCULARIZATION: THE TASK FORCE ON MYOCARDIAL REVASCULARIZATION OF THE EUROPEAN SOCIETY OF CARDIOLOGY (ESC) AND THE EUROPEAN ASSOCIATION FOR CARDIO-THORACIC SURGERY (EACTS) DEVELOPED WITH THE SPECIAL CONTRIBUTION OF THE EUROPEAN ASSOCIATION OF PERCUTANEOUS CARDIOVASCULAR INTERVENTIONS (EAPCI). Eur Heart J, 35, 2014, p. 2541.

47. WILLIAMS, K., PROBST, H. USE OF IV CONTRAST MEDIA IN RADIOTHERAPY PLANNING CT SCANS: A UK AUDIT, Radiography, 22, Suppl 1, 2016, p. 28.

48. HONG, S., I., AHN, S., LEE, Y., S., KIM, W., Y., LIM, K., S., LEE, J., H., LEE, J., L. CONTRAST-INDUCED NEPHROPATHY IN PATIENTS WITH ACTIVE CANCER UNDERGOING CONTRAST-ENHANCED COMPUTED TOMOGRAPHY. Support Care Cancer, 24, 2016, p. 1011.

49. HELleR, C., A., KNAPP, J., HALlidAY, J., O'CONNELl, D., HELlER, R., F. FAILURE TO DEMONSTRATE CONTRAST NEPHROTOXICITY. Med J Aust, 155, 1991, p. 329.

50. SKINNER, R., KAPLAN, R., NATHAN, P., C. RENAL AND PULMONARY LATE EFFECTS OF CANCER THERAPY. Semin Oncol, 40, 2013, p. 757.

51. SENDUR, M., A., AKSOY, S., YAMAN, S., ARIK, Z., TUGBA KOS, F., AKINCI, M., B., CIVELEK, B., YILDIRIM OZDEMIR, N., UNCU, D., ZENGIN, N. ADMINISTRATION OF CONTRAST MEDIA JUST BEFORE CISPLATIN-BASED CHEMOTHERAPY INCREASES CISPLATININDUCED NEPHROTOXICITY. J BUON, 18, 2013, p. 274.

52. LAUNAY-VACHER, V., OUDARD, S., JANUS, N., GLIGOROV, J., POURRAT, X., RIXE, O., MORERE, J., F., BEUZEBOC, P., DERAY, G., RENAL INSUFFICIENCY AND CANCER MEDICATIONS (IRMA) STUDY GROUP. PREVALENCE OF RENAL INSUFFICIENCY IN CANCER PATIENTS AND IMPLICATIONS FOR ANTICANCER DRUG MANAGEMENT. Cancer, 110, 2007, p. 1376.

53. LEVEY, A., S., BOSCH, J., P., LEWIS, J., B., GREENE, T., ROGERS, N., ROTH, D. A MORE ACCURATE METHOD TO ESTIMATE GLOMERULAR FILTRATION RATE FROM SERUM CREATININE: A NEW PREDICTION EQUATION. MODIFICATION OF DIET IN RENAL DISEASE STUDY GROUP. Ann Intern Med, 130, 1999, p. 461.

54. DIMOPOULOS, M.,A., KASTRITIS, E., ROSINOL, L., BLADE, J., LUDWIG, H. PATHOGENESIS AND TREATMENT OF RENAL FAILURE IN MULTIPLE MYELOMA. Leukemia, 22, 2008, p. 1485.

55. PAHADE, J., K., LEBEDIS, C., A., RAPTOPOUlOS, V., D., AVIGAN, D., E., YAM, C., S., KRUSKAL, J., B., PEDROSA, I. INCIDENCE OF CONTRAST-INDUCED NEPHROPATHY IN PATIENTS WITH MULTIPLE MYELOMA UNDERGOING CONTRAST-ENHANCED CT. AJR Am J Roentgenol, 196, 2011, p. 1094.

Manuscript received: 12.12 .2019 